Queiroz, V., Arizza, V., Vazzana, M., Rozas, E.E., \& Custódio, M.R. (2021). Cytocentrifugation as an additional method to study echinoderm coelomocytes: a comparative approach combining living cells, stained preparations, and energy-dispersive $\mathrm{x}$-ray spectroscopy. Revista de Biología Tropical, 69(S1), 171-184. DOI 10.15517/rbt.v69iSuppl.1.46348

DOI 10.15517/rbt.v69iSuppl.1.46348

\title{
Cytocentrifugation as an additional method to study echinoderm coelomocytes: a comparative approach combining living cells, stained preparations, and energy-dispersive x-ray spectroscopy
}

\author{
Vinicius Queiroz ${ }^{1 *}$ \\ Vincenzo Arizza ${ }^{2}$ \\ Mirella Vazzana ${ }^{2}$ \\ Enrique E. Rozas ${ }^{3}$ \\ Marcio R. Custódio ${ }^{1,4}$
}

1. Departamento de Fisiologia Geral, Instituto de Biociências, Universidade de São Paulo, São Paulo, Brasil; vinicius_ufba@yahoo.com.br (*Correspondence).

2. Dipartimento di Scienze e Tecnologie Biologiche Chimiche e Farmaceutiche, Universittá degli Studi di Palermo, Palermo, Italy; mirella.vazzana@unipa.it; vincenzo.arizza@unipa.it

3. Departamento de Engenharia Química, Escola Politécnica, Universidade de São Paulo, São Paulo, Brasil; isoquir@gmail.com

4. Núcleo de Pesquisa em Biodiversidade Marinha da Universidade de São Paulo, São Paulo, Brasil; mcust@usp.br

Received 28-VI-2020. Corrected 28-X-2020. Accepted 10-XI-2020.

\begin{abstract}
Introduction: Echinoderm coelomocytes have traditionally been investigated through a morphological approach using light microscopy, which relies on the idea of constant cell shape as a stable character. However, this can be affected by biotic or abiotic conditions. Objective: To analyze if the consistency in cell morphology offered by the cytocentrifugation method, might be used as a convenient tool to study echinoderm coelomocytes. Methods: Cells of Echinaster (Othilia) brasiliensis (Asteroidea), Holothuria (Holothuria) tubulosa (Holothuroidea), Eucidaris tribuloides, Arbacia lixula, Lytechinus variegatus, and Echinometra lucunter (Echinoidea) were spread on microscope slides by cytocentrifugation, stained, and analyzed through light microscopy. Additionally, fluorescence microscopy, scanning electron microscopy, and energy-dispersive x-ray spectroscopy were applied to cytospin preparations, to complement the analysis of granular and colorless spherulocytes of Eucidaris tribuloides. Results: Altogether, 11 cell types, including phagocytes, spherulocytes, vibratile cells, and progenitor cells were identified in the samples analyzed. The granular spherulocyte, a newly-described cell type, was observed in all Echinoidea and was very similar to the acidophilic spherulocytes of Holothuria (Holothuria) tubulosa. Conclusions: Cytocentrifugation proved to be versatile, either as the main method of investigation in stained preparations, or as a framework on which other procedures may be performed. Its ability to maintain a constant morphology allowed accurate correspondence between live and fixed/stained cells, differentiation among similar spherulocytes as well as comparisons between similar cells of Holothuroidea and Echinoidea.
\end{abstract}

Key words: comparative cell morphology; echinoderm physiology; energy-dispersive x-ray spectroscopy; invertebrate immunology; spherulocytes; vibratile cells. 
Regardless of the scientific scope (e.g. physiology, environmental monitoring), the identification and classification of echinoderm coelomocytes -the circulating cells present in the coelomic fluid- has been traditionally based on morphological data (Matranga et al., 2005; Arizza, Giaramita, Parrinello, Cammarata, \& Parrinello, 2007). Morphological characterization of coelomocytes primarily relies on two techniques: transmission electron microscopy (TEM) and/or light microscopy (LM) (Smith, 1981).

TEM analyses have provided fine structural details and information of cytoplasmic components, providing insights on cell physiology and function (Queiroz \& Custódio, 2015; Magesky, Oliveira-Ribeiro, Beaulieu, \& Pelletier, 2017). However, such analyses require sophisticated infrastructure, and considerable time must be spent in the preparation of samples. By contrast, based on faster and cheaper procedures, LM allows the observation of cell behavior and detection of morphological traits in living cells (Matranga et al., 2005). With this technique, gross morphology and chemical properties of fixed cells can be investigated (Queiroz \& Custódio, 2015; Vazzana, Siragusa, Arizza, Buscaino, \& Celi, 2015). To perform this procedure, two methods have been employed. The first one consists of fixing cells in suspension just after their collection (Vazzana et al., 2015), while the second one uses the natural ability of living cells to spread and attach themselves to flat surfaces (Branco, Borges, Santos, Junior, \& Silva, 2013).

Light microscopy is an easy and quick method, but it has some disadvantages as well. This procedure is based on cell morphology as a stable character, but coelomocyte morphology can be affected by biotic or abiotic conditions. Phagocytes can switch between petaloid and filiform conformations (Edds, 1977, 1993; Canicattì, D'Ancona, \& Farina-Lipari, 1989), while spherulocytes may transit between rounder and more elongated shapes (Matranga et al., 2005). Similarly, temperature can influence the spreading ability of phagocytes (Branco et al., 2013). Due to this morphological variability, the accurate identification of different cell types by LM may be compromised. For this reason, a method capable of maintaining a consistent cell morphology would be preferred.

Cytospin may be defined as a centrifugation technique that uses centrifugal force to attach cells directly onto microscope slides (Rathert, Roth, \& Soloway, 1993; Gill, 2013). Cytocentrifuges are commonly used in clinical medicine to analyze cells suspended in low-concentrated fluids (e.g. peritoneal and bronchoalveolar; Bibby, 1986; Fleury-Feith, Escudier, Pocholle, Carre, \& Bernaudin, 1987). They are used to spread cells in a single layer, thus concentrating them on a small area and preserving morphological details (Qing-fan, 1986). Although cytocentrifugation dates from the mid-1980s and is a well-established method for cell analyses in clinical medicine, its use is not so widespread among invertebrate scholars, and even less so among echinoderm researchers (Raftos, Gross, \& Smith, 2004; Majeske, Oleksyk, \& Smith, 2013b). To the best of our knowledge, only three (recent) studies have used cytospin preparations to analyze coelomocyte morphology in Echinodermata (Grand, Pratchett, \& Rivera-Posada, 2014; Queiroz \& Custódio, 2015; Taguchi, Tsutsui, \& Nakamura, 2016).

Considering the inherent advantages of cytocentrifugation, as stated by Qing-fan (1986), and the scarcity of studies using this method to analyze coelomocyte morphology, this work aims to address three main questions: 1) Is cytocentrifugation a satisfactory method to investigate coelomocyte morphology in Echinodermata? 2) Could cytospin slides be used in conjunction with other techniques? 3) Would cytocentrifugation be useful in comparing cell morphology of different echinoderm groups? Considering all analyzed groups, i.e. Asteroidea, Holothuroidea, and Echinoidea, we found eleven cell types, which were observed in both live and stained preparations. Cytocentrifugation was used in combination with other methods (e.g. fluorescence microscopy), providing additional data on the spherulocytes of Eucidaris tribuloides. Moreover, this method allowed comparisons between similar 
coelomocytes belonging to different classes of Echinodermata.

\section{MATERIALS AND METHODS}

Specimen maintenance and bleeding procedures: Five specimens of Echinaster (Othilia) brasiliensis (Asteroidea), Eucidaris tribuloides, Lytechinus variegatus, and Echinometra lucunter (Echinoidea) were collected

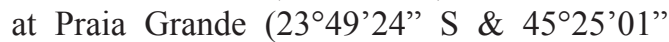
W), São Sebastião (SP), SE Brazil, while five individuals of Holothuria (Holothuria) tubulosa (Holothuroidea) and Arbacia lixula (Echinoidea) were collected in the Gulf of Palermo ( $38^{\circ} 06^{\prime} N$ \& $13^{\circ} 30^{\prime}$ E), Sicily, SW Italy. Brazilian echinoderms were acclimated for one week at $23-25{ }^{\circ} \mathrm{C}$ in a running seawater aquarium and Italian species were acclimated at $12-15{ }^{\circ} \mathrm{C}$. Echinaster (Othilia) brasiliensis was fed with dead crabs, sea urchins, or small fish collected at the same locality, while sea urchins were fed with frozen algae, as described by Queiroz (2018). Echinoderms from Italy were fed with commercial invertebrate food (Azoo, Taikong Corp., Taiwan).

Coelomocytes were collected following specific procedures according to the species. Cells from E. brasiliensis were collected as described by Coteur, DeBecker, Warnau, Jangoux and Dubois (2002), by cutting the tip of one arm and draining $1 \mathrm{~mL}$ of coelomic fluid inside an Eppendorf previously filled with $1 \mathrm{~mL}$ of anticoagulant solution $(20 \mathrm{mM}$ ethylenediamine tetraacetic acid (EDTA), sodium chloride $460 \mathrm{mM}$, sodium sulfate $7 \mathrm{mM}$, potassium chloride $10 \mathrm{mM}$, 4-(2-hydroxyethyl)-1-piperazineethanesulfonic acid (HEPES) $10 \mathrm{mM}$, pH 8.2 - based on Dunham \& Weissman, 1986). This solution was originally developed for marine sponges, but has shown good results also for echinoderms (Queiroz \& Custódio, 2015; Queiroz, 2020). Cells from H. tubulosa were collected following the protocol of Vazzana et al. (2015). Briefly, a $2 \mathrm{~cm}$-long incision on the anterodorsal side of the specimens was made using a sterile scalpel, then $3 \mathrm{~mL}$ of coelomic fluid were drained into $15 \mathrm{~mL}$ falcon tubes containing $3 \mathrm{~mL}$ of anticoagulant solution. Echinoid coelomocytes were collected according to Queiroz and Custódio (2015), by inserting a syringe needle preloaded with 0.5 $\mathrm{mL}$ of isosmotic anticoagulant solution into the peristomial membrane and $0.5 \mathrm{ml}$ of coelomic fluid was withdrawn from each sea urchin.

Cytological preparations: Live cells were observed just after collection by placing drops of coelomic fluid on a microscopic slides, and covered with glass coverslips. For cytological analyses, live cells were deposited on microscope slides using a FANEN 248 simultaneous fluid removal cytocentrifuge. Firstly, the cell density was adjusted to $1 \times 10^{6}$ cells $/ \mathrm{mL}$ by dilute coelomic fluid using the anticoagulant solution. Subsequently, $60 \mu \mathrm{L}$ of the sample $\left(6 \times 10^{4}\right.$ cells $)$ were added in each spot and centrifuged by $5 \mathrm{~min}$ at $80 \mathrm{x} \mathrm{g}$. Afterwards, slides were fixed for $45 \mathrm{~min}$ in formaldehyde sublimate (Custódio, Hajdu, \& Muricy, 2004; Queiroz \& Custódio, 2015), stained with toluidine blue (TB) or Mallory's trichrome (MT) (Behmer, Tolosa, \& Freitas-Neto, 1976) and mounted using Entellan mounting medium (Merck).

Assays with fluorescence microscopy (FM), scanning electron microscopy (SEM), and energy-dispersive x-ray spectroscopy (EDS) were performed to investigate additional application to cytospin preparations. Granular and colorless spherulocytes of E. tribuloides were used as a model to analyze other characteristics of echinoderm coelomocytes. Cells stained with MT were used for FM assays, by analyzing the natural fluorescence of acid fuchsin (excitation: $540 \mathrm{~nm}$ (green); emission: 630 nm (red); Sabnis, 2010). For SEM and EDS analyses, live cells were deposited on round coverslips and fixed in formaldehyde sublimate as described above. Afterwards, the coverslips were washed once in Milli-Q water for 40 minutes, air-dried, attached to stubs using small pieces of double-sided tape, and stored at room temperature in a closed container with silica gel. Just before SEM analyses, the coverslips were sputter-coated with a 40-60 nm 
thick layer of gold and observed in a Sigma VP (Zeiss) scanning electron microscope. For EDS analyses, the coverslips on stubs were analyzed with no further preparations, with the aid of energy-dispersive X-ray spectroscopy coupled to desktop SEM (Phenon world). The results were shown as the mean percentage \pm standard deviation $(\mathrm{M} \pm \mathrm{SD})$ to each element of five cells, and Student's t-tests $(\alpha=0.05)$ were used to analyze differences between distinct cell compartments inside the same cell (e.g. Nucleus X Cytoplasm) or similar compartments in different cell types. To reduce possible mistakes, common elements from the glass coverslip found in the analyses, such as oxygen, silicon, magnesium, and sodium were removed from the results. Percentages were then recalculated based on the remaining elemental percentages.

Cell identification: Live cells of all species were identified immediately after collection based on morphological features. Afterwards, we looked for cells with the same aspect in fixed preparations (cytospin, MET, and EDS) considering general morphology and/or tinctorial characteristics. Phagocytes were identified by their filopodial or petaloid cytoplasmic expansions, while progenitor cells and vibratile cells displayed a central nucleus surrounded by a thin layer of cytoplasm, and a remarkable flagellum respectively. In Holothuroidea and Echinoidea, more than one type of transparent spherulocyte was found. Thus, based primarily on live preparations, general cell morphology and vacuole (spherule) shape were herein considered key characters to discriminate subpopulations. Lastly, identification was confirmed following specific literature from each class/species: Asteroidea (Kanungo, 1984), Holothuroidea (Vazzana et al., 2015), and Echinoidea (Johnson, 1969; Queiroz \& Custódio, 2015).

\section{RESULTS}

Cell observations: Analysis performed on live and stained cells identified 11 cell types in the three echinoderm classes, distributed into four broad categories: phagocytes, progenitor cells, vibratile cells, and spherulocytes (Fig. 1, Fig. 2).

Asteroidea: Only phagocytes were observed in live preparations of E. (Othilia) brasiliensis, showing a central nucleus and a largely vacuolated cytoplasm (Fig. 1A). Our analysis of microscope slides revealed that live cells spread immediately after collection, and that live and stained phagocytes display a very similar morphology (Fig. 1D). Progenitor cells and colorless spherulocytes were observed in stained preparations (data not shown), however, they were not found in living preparations.

Holothuroidea: Five cell types were found in H. (Holothuria) tubulosa: phagocytes (filopodial and petaloid morphotypes), progenitor cells, spherulocytes, morula cells, and acidophilic spherulocytes. Live filopodial phagocytes show a central body with several filopodia (Fig. 1B), while petaloid phagocytes display several lamellipodia (Fig. 1C), and the same general patterns were observed in all cytospin preparations (Fig. 1E, 1F). Progenitor cells show a prominent nucleus surrounded by a thin cytoplasmic layer not always visible in live cells (Fig. 1G), which became more evident in TB stained preparations (Fig. 1K). Spherulocytes had a prominent nucleus and round finely granular vacuoles (Fig. 1H) that showed affinity to methyl blue in MT preparations (Fig. $1 \mathrm{~L}$ ), indicating the presence of mucopolysaccharides in the spherules. Also, we verified that the cells usually called "morula" (Vazzana et al., 2015) are actually coelomocytes containing spherules with irregular profile (from round to more elongated). They also stain with methyl blue in MT preparations, evidencing its mucopolysaccharide content (Fig. 1I, Fig. 1M). Acidophilic spherulocytes bear round spherules, with affinity to acid fuchsin in MT preparations, which indicates a protein-moiety (Fig. 1J, Fig. 1N). 

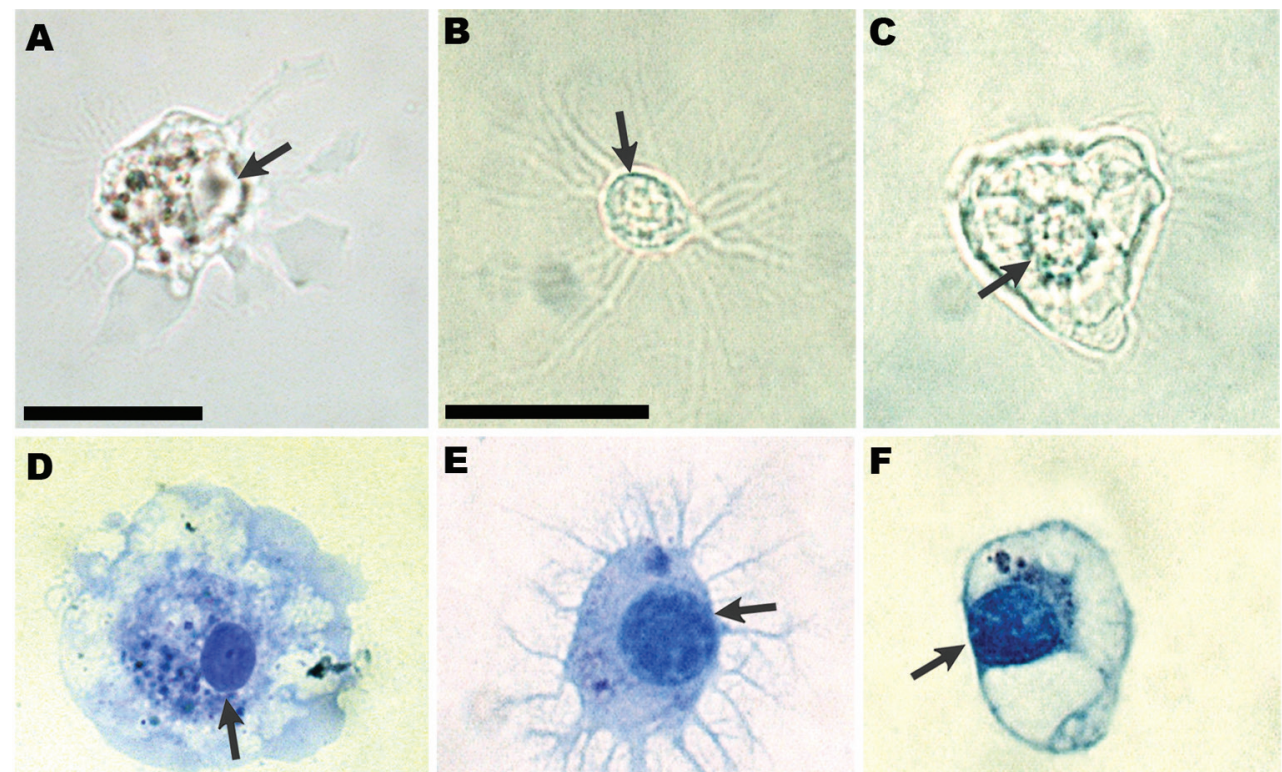

$\mathbf{E}$

$\mathbf{F}$
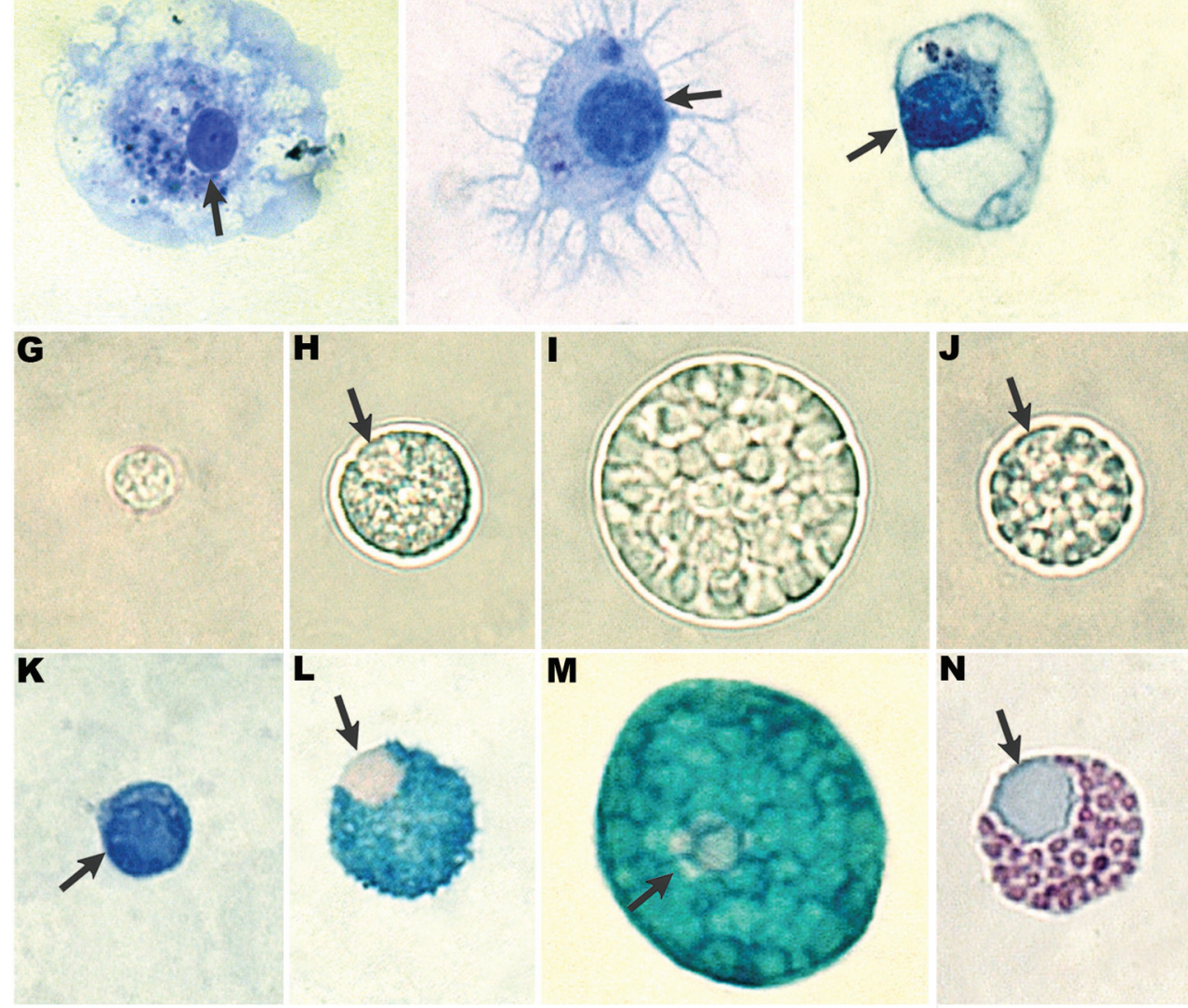

$\mathbf{N}$

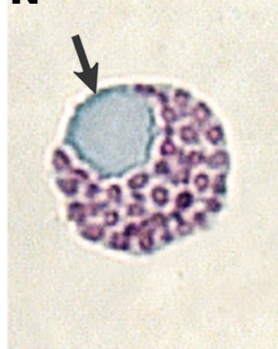

Fig. 1. Live (A-C and G-J) and stained (D-F and K-N) coelomocytes of Echinaster (Othilia) brasiliensis (A and D) and Holothuria (Holothuria) tubulosa (B, C, and E-N). A-F. Phagocytes. G, K. Progenitor cell. H, L. Spherulocytes. I, M. Morula cell. J, N. Acidophilic spherulocyte. D-K. Toluidine Blue. L-N. Mallory's trichrome. Arrow = nucleus. Scales: A. For cells of Echinaster (Othilia) brasiliensis $(10 \mu \mathrm{m})$, B. For cells of Holothuria (Holothuria) tubulosa $(10 \mu \mathrm{m})$.

Echinoidea: Five coelomic subpopulations were observed in all analyzed species: phagocytes, vibratile cells, red and colorless spherulocytes, and one new cell type: the granular spherulocyte. Phagocytes showed a prominent cell body with petal-like cytoplasmic expansions (Fig. 2A'). In cytospin preparations, these cells were irregular in shape, ranging from elongated to roundish, with a subcentral nucleus and a vacuolated cytoplasm 
as key features (Fig. 2A, 2F, 2K, 2P). Vibratile cells are round flagellated spherule-filled coelomocytes (Fig. 2B'), which stains light blue in MT (Fig. 2B, 2L, 2Q) or purplish in TB preparations (Fig. 2G), the latter indicating the presence of glycosaminoglycans in the spherules. Live red spherulocytes were readily noticed by the round red spherules present in live cells (Fig. 2C', 2U, 2V, 2W). These cells do not stain in MT slides but present a characteristic brownish color (Fig. 2C, 2H, 2M, 2R), probably due to echinochrome. Even in fixed but not stained preparations, the brownish color is characteristic. Lastly, two types of transparent spherulocytes were identified in Echinoidea, named colorless and granular spherulocytes. Live cells of the first type displayed transparent spherules of variable shape (ranging from roundish to elongated - Fig. 2D'), while live granular spherulocytes showed round uniform spherules (Fig. 2E'). In MT preparations, colorless spherulocytes stained bluish (Fig. 2D, 2I, 2N, $2 \mathrm{~S}$ ), and granular spherulocytes stained pinkish, indicating that their vacuoles are filled with mucopolysaccharides and protein, respectively.

\section{Analysis of granular and colorless spherulocytes of Eucidaris tribuloides using FM, SEM, and EDS: Fluorescence analysis of granular and colorless spherulocytes, previ- ously observed in brightfield microscopy (Fig. $3 \mathrm{~A}$ ), showed an intense red fluorescence in the MT preparation due to the affinity of acid fuch- sin for granules, which was not observed in the nucleus (Fig. 3B). On the other hand, colorless}

spherulocytes stained with MT did not show fluorescence (Fig. 3B). SEM analyses allowed a detailed observation of spherulocyte morphology (Fig. 3C, 3D). While granular spherulocytes showed the usual spherical cell shape and regular-sized spherules (Fig. 3C), colorless spherulocytes showed a variable shape, ranging from spherical to more elongated, which was also observed in the spherules (Fig. 3D).

Coelomocyte characterization by SEM was essential to study the elemental composition of the nucleus $(\mathrm{Nu})$ and cytoplasm $(\mathrm{Cy})$ in both cells using EDS (Fig. 3E). For granular spherulocytes, in both nucleus and cytoplasm compartments, the most representative elements were carbon, nitrogen, and sulfur, while phosphorus and calcium were the less common (Table 1). The colorless spherulocyte followed a similar pattern, with some differences. Carbon, nitrogen, and calcium were the most representative elements, and phosphorus and sulfur were the less common (Table 1). Statistical analyses corroborated the differences in elemental composition between distinct compartments in the same cell, or between similar compartments in different cells (Fig. 3E). Thus, the elemental composition of nitrogen, sulfur, and calcium was different between the nucleus and cytoplasm of granular spherulocytes, while sulfur differed in the colorless spherulocyte (Fig. 3E). Comparisons between both spherulocytes showed differences in the composition of nuclear carbon and sulfur, and cytoplasmic carbon, nitrogen, sulfur, and calcium (Fig. 3E).

TABLE 1

Percentage (\%) of the main chemical elements in the colorless and granular spherulocytes of Eucidaris tribuloides. Values are presented as mean \pm standard deviation $(\mathrm{M} \pm \mathrm{SD})$. Legend: $\mathrm{C}=$ Carbon, $\mathrm{N}=$ Nitrogen, $\mathrm{P}=$ Phosphorus, $\mathrm{S}=$ Sulfur, $\mathrm{Ca}=$ Calcium

\begin{tabular}{ccccc}
\multirow{2}{*}{ Chemical element } & \multicolumn{2}{c}{ Colorless Spherulocytes } & \multicolumn{2}{c}{ Granular Spherulocytes } \\
\cline { 2 - 5 } C & Nucleus & Cytoplasm & Nucleus & Cytoplasm \\
N & $51.90 \pm 6.61$ & $57.30 \pm 9.18$ & $43.80 \pm 3.57$ & $43.70 \pm 4.91$ \\
P & $27.16 \pm 5.02$ & $24.80 \pm 5.23$ & $27.20 \pm 5.97$ & $42.42 \pm 5.78$ \\
S & $3.16 \pm 1.66$ & $1.64 \pm 1.23$ & $5.76 \pm 5.67$ & $0.46 \pm 0.30$ \\
$\mathrm{Ca}$ & $8.12 \pm 1.51$ & $3.36 \pm 1.56$ & $16.90 \pm 4.99$ & $10.34 \pm 2.17$ \\
\hline
\end{tabular}



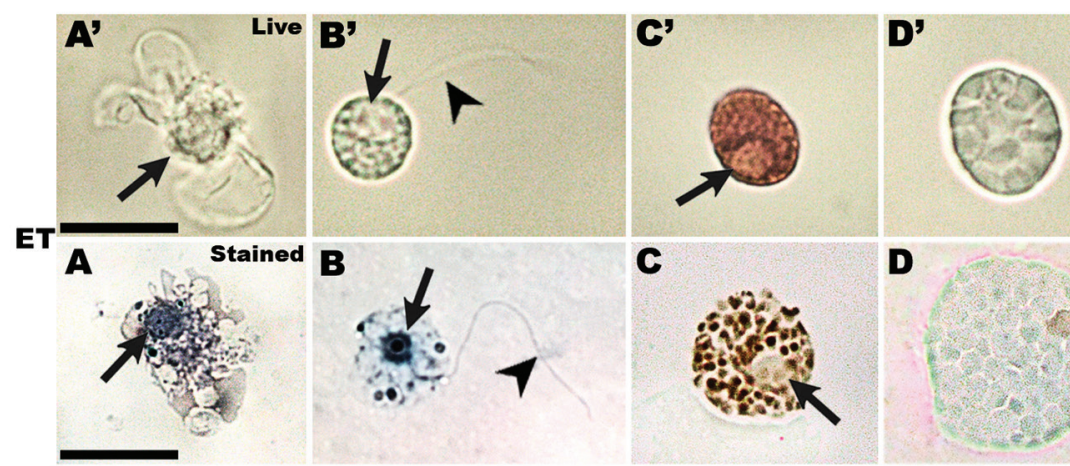

E'

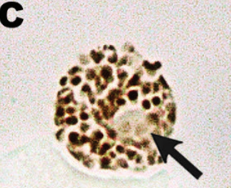

D
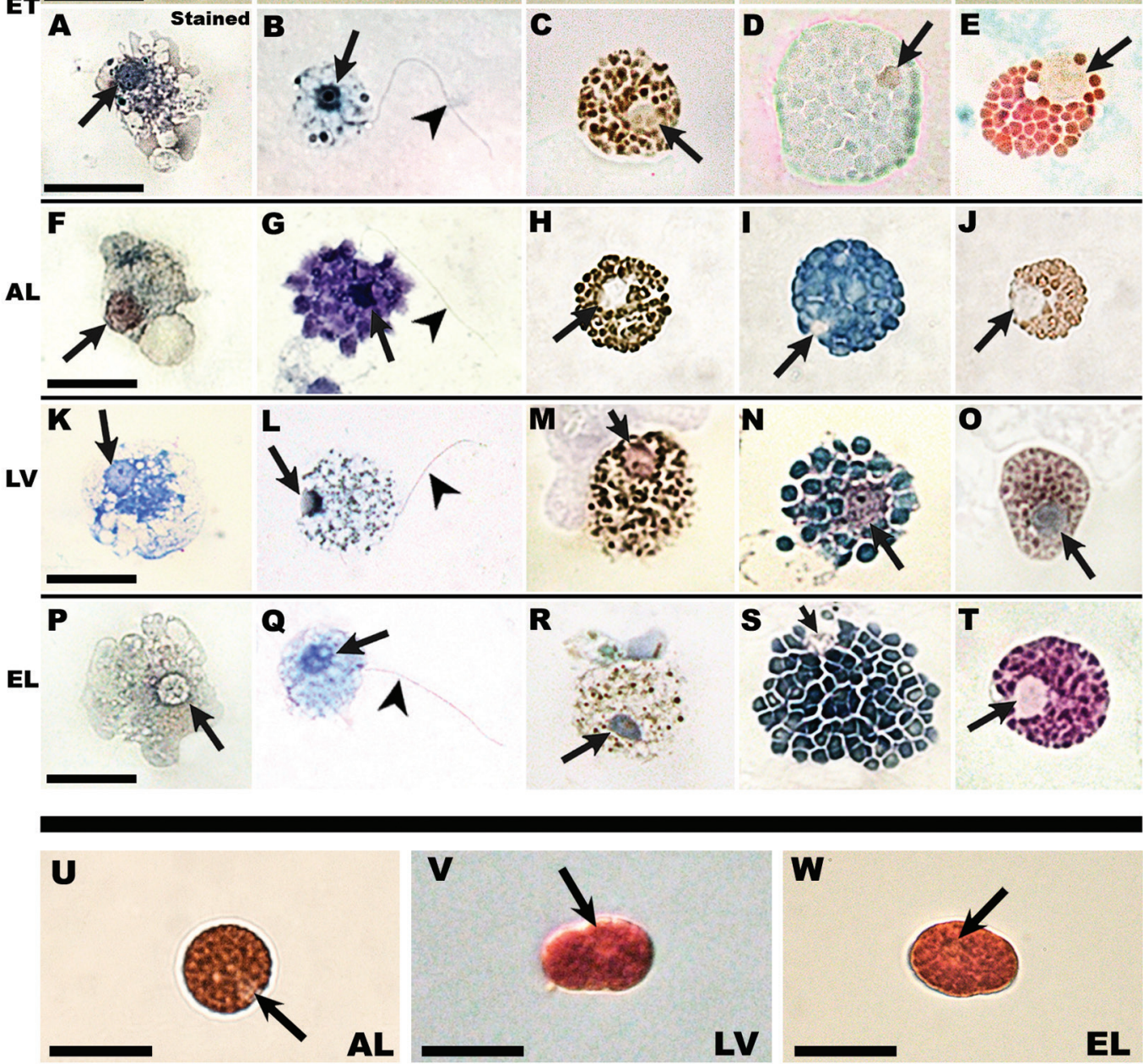

Fig. 2. Live and stained coelomocytes of Echinoidea. A'-E', A-E. Eucidaris tribuloides (ET). F-J. Arbacia lixula (AL). K-O. Lytechinus variegatus (LV). P-T. Echinometra lucunter (EL). U-W. Live red spherulocytes of Arbacia lixula, Lytechinus variegatus, and Echinometra lucunter. A', A, F, K, P. Phagocytes. B', B, G, L, Q. Vibratile cells. C', C, H, M, R. Red spherulocytes. D', D, I, N, S. Colorless spherulocytes. E', E, J, O, T. Granular spherulocyte. A-F, H-J, and L-T. Mallory's trichrome. G, K. Toluidine blue Arrow = nucleus. Arrowhead = flagellum. Scales =10 $\mu \mathrm{m} ; \mathbf{A}^{\prime}$, A. For live and stained cells respectively of Eucidaris tribuloides. F. For stained cells of Arbacia lixula. K. For stained cells of Lytechinus variegatus. P. For stained cells of Echinometra lucunter. 

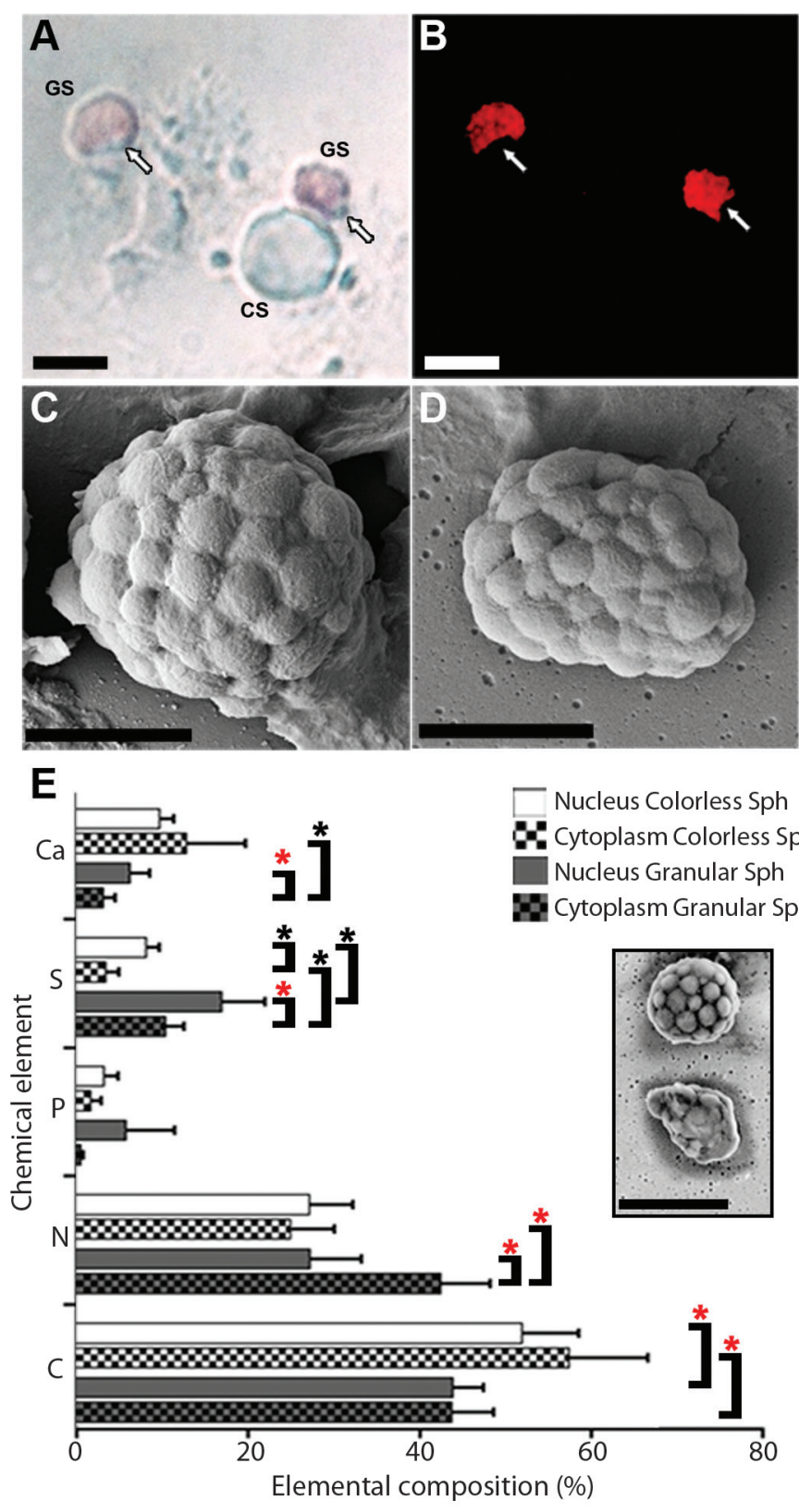

Fig. 3. Granular and colorless spherulocytes of Eucidaris tribuloides studied under different methods. A, B. Light and fluorescence microscopy of Mallory's trichrome-stained granular and colorless spherulocytes. C, D. Detailed morphology of the granular and colorless spherulocytes respectively, under scanning electron microscopy. E. Elemental composition of cytoplasm and nucleus of granular and colorless spherulocytes in energy-dispersive $\mathrm{x}$-ray spectroscopy, and morphology of granular and colorless spherulocytes in EDS analysis (Inset). $\mathrm{C}=$ Carbon. $\mathrm{N}=$ Nitrogen. $\mathrm{S}=$ Sulfur. $\mathrm{P}=\mathrm{Phosphorous.} \mathrm{Ca}$ $=$ Calcium. $\mathrm{CS}=$ Colorless spherulocyte. $\mathrm{GS}=$ Granular spherulocyte. Red asterisk $=\mathrm{P}<0.05$. Black asterisk $=\mathrm{P}<0.01$. White arrow $=$ Granular spherulocyte nucleus. Scale: A, B, E $=10 \mu \mathrm{m} ; \mathrm{C}, \mathrm{D}=5 \mu \mathrm{m}$. 


\section{DISCUSSION}

In the present study, we confirmed that: 1) cytocentrifugation was satisfactory to analyze coelomocyte morphology in Echinodermata, revealing 11 cell types in the six species analyzed; 2) cytospin slides can be used along with other techniques, providing additional relevant data, and 3) cytocentrifugation allowed us to compare coelomocytes of different echinoderms classes. Considering these results, it can be suggested that cytocentrifugation is an improved method for additional analysis in coelomocyte studies in Echinodermata.

Through cytocentrifugation, coelomocytes are forced to spread onto slides in short runs, binding more efficiently and faster than when allowed to adhere under passive conditions. Incubating cells from suspensions and waiting for them to settle, attach, and spread, has been the most usual procedure to attach coelomocytes on flat surfaces (Bertheussen \& Seljelid, 1978; Romero, Novoa, \& Figueras, 2016). This poses three main problems: 1) The ability to attach and spread on surfaces is not observed in some coelomic populations (e.g., vibratile cells), which are usually lost during slide processing (Romero et al., 2016); 2) The timespan to achieve cell adhesion may be very long (Romero et al., 2016), which can lead to the degradation and loss of cell characters; 3) The ability to attach and spread on the glass surface, and consequently the cell morphology, can be affected by environmental conditions, such as temperature (Branco et al., 2013). We understand that in some specific situations where the preservation of the natural shape of coelomocytes is necessary (e.g. Edds, 1993; Majeske, Bayne, \& Smith, 2013a), cytocentrifugation may not be the best protocol to access cell morphology. However, cytospin preparations are more efficient compared to the usual method, since all cell types can be spread onto common microscope slides without further preparation (e.g. Poly-L lysine; Majeske et al., 2013b), within a short period, and their morphology did not vary considerably.
To the best of our knowledge, only three studies have used cytocentrifugation to analyze echinoderm coelomocyte morphology (Grand et al., 2014; Queiroz \& Custódio, 2015; Taguchi et al., 2016), and all of them showed a high potential to improve cell analyses in Echinodermata. Only phagocytes and small spherical cells were previously known to the sea star Acanthaster planci (Boolotian, 1962). Howev$\mathrm{er}$, in a study using cytocentrifugation, Grand et al. (2014) described four distinct coelomocytes to this species, showing that its coelomocyte diversity may have been underestimated. Similarly, a new spherulocyte was also detected in E. tribuloides (Queiroz \& Custodio, 2015), and for the first time, spherulocytes were reported to be able to phagocyte foreign particles (Tagushi et al., 2016). In the same way, we also obtained an unequivocal correspondence between living and fixed cells of all analyzed species, and for the first time, we report a fifth cell type -the granular spherulocyte- in the well-studied echinoids A. lixula, L. variegatus, and E. lucunter (Branco et al., 2013). Thus, our data show that this method can improve morphological descriptions by relating living and fixed cells. It was also able to demonstrate that the newly-described granular spherulocyte (Queiroz \& Custodio, 2015) is not restricted to E. tribuloides, and may be widespread among regular echinoids.

Another important result obtained herein was the possibility to differentiate spherulocyte subpopulations in fixed preparations. These subpopulations are identified due to their spherule-filled cytoplasm and named after the characteristics of living cells, but are yet a poorly understood cell type in Echinodermata (Ramírez-Gómez \& García-Arrarás, 2010). Still, even when alive, spherulocyte identification may be imprecise because more than one type of "transparent" spherulocyte may be present, as we report herein. Consequently, the correct identification of live or fixed cells is still difficult. However, we demonstrate herein that cytocentrifugation is a useful alternative method to discriminate spherulocytes since it allows a good correlation between live and 
fixed/stained cells. For example, three different subpopulations were unequivocally identified in live and fixed preparation of $H$. (Holothuria) tubulosa, E. tribuloides, A. lixula, L. variegatus, and E. lucunter, and differentiated by cell profile and vacuoles shape (when alive), and its stain affinity (in fixed preparations). By contrast, the correspondence between live and fixed spherulocytes of Holothuria (Selenkothuria) glaberrima (see Fig. 2A-C in Ramírez-Gómez, Aponte-Rivera, Méndez-Castaner, \& GarcíaArrarás, 2010) and Echinometra mathaei (see Fig. 5 in Piryaei, Ghavam-Mostafavi, Ghavam-Mostafavi, \& Pooshang-Bagheri, 2018) leaves some doubts. We strongly believe that correspondence between live and fixed preparations could be increased if cytocentrifugation had been used to prepare the samples in these studies.

Although cellular characteristics obtained by light and even electron microscopy may fail to identify homologous cell types between distinct phyla, these methods might be a useful tool between closer species (Arendt, 2008). Thus, the morphological approach presented here can be used to compare cells from different echinoderm classes, and the acidophilic and granular spherulocytes provide one interesting example. These two coelomocytes are identified by their transparent color and spherule shapes (Vazzana et al., 2015; Vazzana et al.,2018; Queiroz \& Custodio, 2015). Both spherulocytes showed uniform spherules filled with a peptidic moiety, as showed by the pinkish color produced by the acid fuchsine present in MT solution. We recognize that even though morphology and chemical contents are similar, further studies are still necessary. Only the discovery of specific cell markers - such as those expressed in helper and cytotoxic lymphocytes (Taniuchi, 2018) - can elucidate this issue. However, the approach used herein can improve the understanding of spherulocyte diversity and can certainly be employed as an additional strategy to understand the real nature of vibratile cells in Echinodermata (Hetzel, 1963; Xing, Yang, \& Chen, 2008; Smith et al., 2018).
Cytocentrifugation is also quite useful as a preparation method, alongside which other procedures may be performed, mainly when the aim is to analyze coelomocyte diversity. Some studies used cytospin preparation as a framework for FM (Clow, Raftos, Gross, \& Smith, 2004; Majeske et al., 2013b; Golconda, Buckley, Reynolds, Romanello, \& Smith, 2019) or SEM (Grand et al., 2014). However, only two of these works (Clow, Raftos, Gross, \& Smith, 2004; Grand et al., 2014) analyzed cell morphology using cytocentrifugation. Using cytospins, further aspects of the granular spherulocyte were analyzed herein by different techniques. FM revealed that, in addition to the morphological characteristics, the red fluorescence of the protein-filled spherules may be an identification marker, while SEM corroborated the differences in the shape pattern of cytoplasmic spherules observed in light and fluorescence microscopy.

EDS has been commonly used to analyze the presence of uncommon elements (e.g. heavy metals) in invertebrate coelomocytes/ hemocytes (e.g. Tullius, Gillum, Carlson, \& Hodgson, 1980), but few studies have focused on conventional cell elements (Scippa, De Vincentiis, \& Zierold, 1990). This method revealed specific differences in the elemental composition in different compartments of the same cell as well as between similar compartments of different cells, which could reflect organelle functioning. For example, sulfur was higher in the nucleus if compared to the cytoplasm of the granular and colorless spherulocytes of $E$. tribuloides, a pattern similar to that observed in the morula cell of the urochordates Halocynthia papillosa and Phallusia mammillata (Scippa, Botte, Zierold, \& De Vincentiis, 1985; Scippa, De Vincentiis, \& Zierold, 1993). By constrast, although nitrogen has not been mentioned to other invertebrates (e.g. Scippa et al., 1990; Scippa et al., 1993; Giamberini, Auffret, \& Pihan, 1996), this element was higher in granular but not in colorless spherulocytes.

Higher nuclear sulfur can indicate higher levels of Methionine, an amino acid universally associated with the initiation of protein 
synthesis (Kozak, 1983). Such an explanation fits properly with the general function of the morula cell of $H$. papillosa and spherulocytes of E. tribuloides, which are cells adapted to produce and store chemical compounds. In contrast, higher cytoplasmic nitrogen corroborates the assumptions of a rich-protein moiety observed through acid fuchsin affinity. Lastly, if considered in conjunction, the two-fold levels of nuclear sulfur and cytoplasmic nitrogen observed in granular spherulocytes confirm the engagement of this cell in protein production. Therefore, our results suggest that sulfur and nitrogen concentrations are different in colorless and granular spherulocytes of E. tribuloi$d e s$, and could be used as a specific chemical marker to differentiate these cells in other echinoids. This approach could provide important results in the cells of other invertebrates.

Most studies addressing echinoderm coelomocytes by FM, either using cytospin preparations (Clow, Raftos, Gross, \& Smith, 2004; Golconda et al., 2019) or other methods (Brockton et al., 2008; Majeske et al., 2013a), have focused on sea urchin phagocytes, while spherulocytes, in general, have been poorly studied (García-Arrarás et al., 2006; Falugi et al., 2012). That may be due to the ease in identifying phagocyte subpopulations. Even with the use of specific markers to discriminate phagocyte subtypes, the identification is still mostly based on morphology (Golconda et al., 2019). To SEM, although Grand et al. (2014) have used cytocentrifugation to analyze A. planci coelomocytes, the authors did not provide a more detailed correspondence among the living, stained, and SEM preparations, which impairs further comparisons. Regarding EDS, as far as we know, there is no work using cytocentrifugation to perform this technique. However, Falugi et al. (2012) used an Environmental Scanning Electron Microscope coupled with EDS to analyze the presence of nanoparticles in smeared cells. In this latter study, which certainly provided important data on the effect of nanoparticles on echinoderm coelomocytes, some additional aspects could have been observed if cytocentrifugation was used. For example, in addition to confirming the presence of $\mathrm{Sn}, \mathrm{Ce}$, and $\mathrm{Fe}$ inside the coelomocytes, and observing impacts on subcellular compartments, Falugi et al. (2012) could have answered other relevant questions, such as: 1) Do different cell types accumulate nanoparticles equally? 2) Can nanoparticles be found in the nucleus? 3) Which cell type was most impacted at the subcellular level? Consequently, our results show that cytocentrifugation could be a useful tool to improve studies on coelomocyte in Echinodermata and other invertebrates as well.

Cytocentrifugation proved to be versatile, being useful as the main method to investigate echinoderm cell morphology in stained preparations or as a framework for other procedures. Although stained phagocytes displayed little variations if compared to live cells, cell identification was not impaired. Therefore, cytocentrifugation maintains constant cell morphology, which allowed accurate correspondence between live and fixed/stained cells, correct identification of apparently similar types of spherulocytes, as well as comparisons between related species. Still, it is a fast, practical, and inexpensive method, useful to different samples. This includes low concentrated cell suspensions, which would allow the study of species with little body fluid volumes such as Crinoidea and Ophiuroidea. Finally, this method may be used either as a convenient strategy able to improve cell morphology or coelomocyte physiology studies. Thus, the present work provides strong evidence that cytospin preparations have a high potential to improve coelomocyte analyses in Echinodermata and other invertebrates.

Ethical statement: authors declare that they all agree with this publication and made significant contributions; that there is no conflict of interest of any kind; and that we followed all pertinent ethical and legal procedures and requirements. All financial sources are fully and clearly stated in the acknowledgements section. A signed document has been filed in the journal archives. 


\section{ACKNOWLEDGMENTS}

The authors thank Sheila Schuindt and Márcio Cruz, Instituto de Biociências (IBUSP), for their help in the SEM analyses. The author is indebted to Daniel C. Cavallari for the English improvements. This work was supported by FAPESP (Proc. 2013/50218-2, 2015/21460-5, and 2018/14497-8) and Coordenação de Aperfeiçoamento de Pessoal de Nível Superior-Brazil (CAPES Finance Code 001), and is a contribution of NP-BioMar (Research Center for Marine Biodiversity, USP).

\section{RESUMEN}

\section{Citocentrifugación como un método adicional para estudiar celomitos de equinodermos: un enfoque comparativo que combina células vivas, preparaciones teñidas y espectroscopía de rayos-x de dispersión de energía}

Introducción: Los celomocitos de equinodermos se han investigado tradicionalmente a través de un enfoque morfológico utilizando microscopía óptica, que se basa en la idea de la forma celular constante como un carácter estable. Sin embargo, esto puede verse afectado por condiciones bióticas o abióticas. Objetivo: Analizar si la consistencia en la morfología celular que ofrece el método de citocentrifugación podría utilizarse como una herramienta conveniente para estudiar los celomocitos de equinodermos. Métodos: Células de Echinaster (Othilia) brasiliensis (Asteroidea), Holothuria (Holothuria) tubulosa (Holothuroidea), Eucidaris tribuloides, Arbacia lixula, Lytechinus variegatus y Echinometra lucunter (Echinoidea) se esparcieron en portaobjetos de microscopio por citocentrifugación, se tiñeron y analizaron mediante microscopía óptica. Adicionalmente, se aplicó microscopía de fluorescencia, microscopía electrónica de barrido y espectroscopía de rayos X con dispersión de energía a las preparaciones de citoespina, para complementar el análisis de los esferulocitos granulares e incoloros de Eucidaris tribuloides. Resultados: En total, se identificaron en las muestras analizadas 11 tipos de células, incluidos fagocitos, esferulocitos, células vibrátiles y células progenitoras. El esferulocito granular, un tipo de célula recién descrito, se observó en todos los Echinoidea y fue muy similar a los esferulocitos acidófilos de Holothuria (Holothuria) tubulosa. Conclusiones: La citocentrifugación demostró ser un método bastante versátil, ya sea como el método principal de investigación en preparaciones teñidas o como un marco en el que se pueden realizar otros procedimientos. Su capacidad para mantener una morfología constante permitió una correspondencia precisa entre las células vivas y las células fijas/teñidas, la diferenciación entre esferulocitos similares, así como comparaciones entre células similares de Holothuroidea y Echinoidea.

Palabras clave: morfología celular comparativa; fisiología de equinodermos; espectroscopía de rayos-x de energía dispersiva; inmunología de invertebrados; esferulocitos; células vibrátiles.

\section{REFERENCES}

Arendt, D. (2008). The evolution of cell types in animals: emerging principles from molecular studies. Nature Reviews Genetics, 9(11), 868-882.

Arizza, V., Giaramita, F.T., Parrinello, D., Cammarata, M., \& Parrinello, N. (2007). Cell cooperation in coelomocyte cytotoxic activity of Paracentrotus lividus coelomocytes. Comparative Biochemistry and Physiology Part A: Molecular \& Integrative Physiology, 147(2), 389-394.

Behmer, O.A., Tolosa, E.M.C., \& Freitas-Neto, A.G. (1976). Manual de técnicas de histologia normal e patológica. São Paulo, Brazil: Edart/Edusp.

Bertheussen, K., \& Seljelid, R. (1978). Echinoid phagocytes in vitro. Experimental Cell Research, 111(2), 401-412.

Bibby, M. (1986). Preparation of Cytospin slides from bloody fluids. Laboratory Medicine, 17(4), 228.

Boolotian, R.A. (1962). The perivisceral elements of echinoderm body fluids. American Zoologist, 2, 275-284.

Branco, P.C., Borges, J.C.S., Santos, M.F., Junior, B.E.J., \& da Silva, J.R.M.C. (2013). The impact of rising sea temperature on innate immune parameters in the tropical subtidal sea urchin Lytechinus variegatus and the intertidal sea urchin Echinometra lucunter. Marine Environmental Research, 92, 95-101.

Brockton, V., Henson, J.H., Raftos, D.A., Majeske, A.J., Kim, Y.O., \& Smith, L.C. (2008). Localization and diversity of $185 / 333$ proteins from the purple sea urchin-unexpected protein-size range and protein expression in a new coelomocyte type. Journal of Cell Science, 121(3), 339-348.

Canicattì, C., D’Ancona, G., \& Farina-Lipari, E. (1989). The coelomocytes of Holothuria polii (Echinodermata). I. Light and electron microscopy. Bollettino di Zoologia, 56(1), 29-36.

Clow, L.A., Raftos, D.A., Gross, P.S., \& Smith, L.C. (2004). The sea urchin complement homologue, $\mathrm{SpC} 3$, functions as an opsonin. Journal of Experimental Biology, 207(12), 2147-2155.

Coteur, G., DeBecker, G., Warnau, M., Jangoux, M., \& Dubois, P. (2002). Differentiation of immune cells 
challenged by bacteria in the common European starfish, Asterias rubens (Echinodermata). European Journal of Cell Biology, 81(7), 413-418.

Custódio, M.R., Hajdu, E., \& Muricy, G. (2004). Cellular dynamics of in vitro allogeneic reactions of Hymeniacidon heliophila (Demospongiae: Halichondrida). Marine Biology, 144, 999-1010.

Dunham, P., \& Weissmann, G. (1986). Aggregation of marine sponge cells induced by $\mathrm{Ca}$ pulses, $\mathrm{Ca}$ ionophores, and phorbol esters proceeds in the absence of external Ca. Biochemical and Bbiophysical Rresearch Ccommunications, 134(3), 1319-1326.

Edds, K.T. (1977). Dynamic aspects of filopodial formation by reorganization of microfilaments. The Journal of cell biology, 73(2), 479-491.

Edds, K.T. (1993). Cell biology of echinoid coelomocytes: I. Diversity and characterization of cell types. Journal of Invertebrate Pathology, 61(2), 173-178.

Falugi, C., Aluigi, M.G., Chiantore, M.C., Privitera, D., Ramoino, P., Gatti, M.A., Matranga, V. (2012). Toxicity of metal oxide nanoparticles in immune cells of the sea urchin. Marine Environmental Research, 76, 114-121.

Fleury-Feith, J., Escudier, E., Pocholle, M.J., Carre, C., \& Bernaudin, J.F. (1987). The effects of cytocentrifugation on differential cell counts in samples obtained by bronchoalveolar lavage. Acta Cytologica, 31(5), 606-610.

García-Arrarás, J.E., Schenk, C., Rodrígues-Ramírez, R., Torres, I.I., Valentín, G., \& Candelaria, A.G. (2006). Spherulocytes in the echinoderm Holothuria glaberrima and their involvement in intestinal regeneration. Developmental dynamics: an official publication of the American Association of Anatomists, 235(12), 3259-3267.

Giamberini, L., Auffret, M., \& Pihan, J.C. (1996). Haemocytes of the freshwater mussel, Dreissena polymorpha Pallas: cytology, cytochemistry and $\mathrm{x}$-ray microanalysis. Journal of Molluscan Studies, 62(3), 367-379.

Gill, G. (2013). Cytopreparation: principles \& practice. New York: Springer Science \& Business Media.

Golconda, P., Buckley, K.M., Reynolds, C.R., Romanello, J.P., \& Smith, L.C. (2019). The axial organ and the pharynx are sites of hematopoiesis in the sea urchin. Frontiers in Immunology, 10, 870.

Grand, A., Pratchett, M., \& Rivera-Posada, J. (2014). The immune response of Acanthaster planci to oxbile injections and antibiotic treatment. Journal of Marine Biology, 2014, 1-11
Hetzel, H.R. (1963). Studies on holothurian coelomocytes. I. A survey of coelomocyte types. The Biological Bulletin, 125(2), 289-301.

Johnson, P.T. (1969). The coelomic elements of sea urchins (Strongylocentrotus). I. The normal coelomocytes; their morphology and dynamics in hanging drops. Journal of Invertebrate Pathology, 13(1), 25-41.

Kanungo, K. (1984). The coelomocytes of asteroid echinoderms. In T.C. Cheng (Ed.), Invertebrate Blood (pp. 7-39). Boston, MA: Springer.

Kozak, M. (1983). Comparison of initiation of protein synthesis in procaryotes, eucaryotes, and organelles. Microbiological Reviews, 47(1), 1-45.

Magesky, A., de Oliveira-Ribeiro, C.A., Beaulieu, L., \& Pelletier, É. (2017). Silver nanoparticles and dissolved silver activate contrasting immune responses and stress-induced heat shock protein expression in sea urchin. Environmental Toxicology and Chemistry, 36(7), 1872-1886

Majeske, A.J., Bayne, C.J., \& Smith, L.C. (2013a). Aggregation of sea urchin phagocytes is augmented in vitro by lipopolysaccharide. PloS One, 8(4), e61419.

Majeske, A.J., Oleksyk, T.K., \& Smith, L.C. (2013b). The Sp185/333 immune response genes and proteins are expressed in cells dispersed within all major organs of the adult purple sea urchin. Innate Immunity, 19(6), 569-587.

Matranga, V., Pinsino, A., Celi, M., Natoli, A., Bonaventura, R., Schröder, H.C., \& Müller, W.E.G. (2005). Monitoring chemical and physical stress using sea urchin immune cells. In V. Matranga (Ed.), Echinodermata. Progress in molecular and subcellular biology (marine molecular biotechnology) (pp. 85-110). Berlin, Heidelberg: Springer.

Piryaei, F., Ghavam-Mostafavi, P., Shahbazzadeh, D., \& Pooshang-Bagheri, K. (2018). Cytological study of Echinometra mathaei (Echinoidea: Camarodonta: Echinometra), the Persian Gulf sea urchin. International Journal of Aquatic Science, 9(2), 77-84.

Qing-fan, Z. (1986). A simplified cytocentrifuge and its clinical application. Journal of Tongji Medical University, 6(4), 256-261.

Queiroz, V. (2018). Opportunity makes the thief-observation of a sublethal predation event on an injured sea urchin. Marine Biodiversity, 48(1), 153-154.

Queiroz, V. (2020). An unprecedented association of an encrusting bryozoan on the test of a live sea urchin: epibiotic relationship and physiological responses. Marine Biodiversity, 50(5), 1-7.

Queiroz, V., \& Custódio, M.R. (2015). Characterisation of the spherulocyte subpopulations in Eucidaris 
tribuloides (Cidaroida: Echinoidea). Italian Journal of Zoology, 82(3), 338-348.

Ramírez-Gómez, F., \& García-Arrarás, J.E. (2010). Echinoderm immunity. Invertebrate Survival Journal, 7, 211-220.

Ramírez-Gómez, F., Aponte-Rivera, F., Méndez-Castaner, L., \& García-Arrarás, J.E. (2010). Changes in holothurian coelomocyte populations following immune stimulation with different molecular patterns. Fish \& Shellfish Immunology, 29(2), 175-185.

Rathert, P., Roth, S., \& Soloway, M.S. (1993). Urinary cytology: manual and atlas. Berlin, Heidelberg: Springer-Verlag.

Romero, A., Novoa, B., \& Figueras, A. (2016). Cell mediated immune response of the Mediterranean sea urchin Paracentrotus lividus after PAMPs stimulation. Developmental \& Comparative Immunology, 62, 29-38.

Sabnis, R.W. (2010). Handbook of biological dyes and stains: synthesis and industrial applications. Hoboken: John Wiley \& Sons, Inc.

Scippa, S., Botte, L., Zierold, K., \& De Vincentiis, M. (1985). X-ray microanalytical studies on cryofixed blood cells of the ascidian Phallusia mammillata. Cell and Tissue Research, 239(2), 459-461.

Scippa, S., De Vincentiis, M., \& Zierold, K. (1990). X-ray microanalytical studies on cryofixed blood cells of the ascidian Phallusia mammillata. III. Quantitative analyses of non-vanadium-accumulating blood cells. Invertebrate Reproduction \& Development, 17(2), 141-146.

Scippa, S., De Vincentiis, M., \& Zierold, K. (1993). Quantitative X-ray microanalysis of the morula cell of the blood of the ascidian Halocynthia papillosa (Stolidobranchiata). Cell and Tissue Research, 271(1), 77-80.

Smith, L.C., Arizza, V., Hudgell, M.A.B., Barone, G., Bodnár, A.G., Buckley, K.M., ... Sutton, E. (2018).
Echinodermata: The complex immune system in echinoderms. In E. Cooper (Ed.), Advances in Comparative Immunology (pp. 409-501). Cham: Springer.

Smith, V.J. (1981). The echinoderms. In N.A. Ratcliffe, \& A.F. Rowley (Eds.), Invertebrate blood cells (pp. 513-562). New York: Academic Press.

Taguchi, M., Tsutsui, S., \& Nakamura, O. (2016). Differential count and time-course analysis of the cellular composition of coelomocyte aggregate of the Japanese sea cucumber Apostichopus japonicus. Fish \& Shellfish Immunology, 58, 203-209.

Taniuchi, I. (2018). CD4 helper and CD8 cytotoxic T cell differentiation. Annual review of Immunology, 36, 579-601.

Tullius, T.D., Gillum, W.O., Carlson, R.M.K., \& Hodgson, K.O. (1980). Structural study of the vanadium complex in living ascidian blood cells by x-ray absorption spectroscopy. Journal of the American Chemical Society, 102(17), 5670-5676.

Vazzana, M., Siragusa, T., Arizza, V., Buscaino, G., \& Celi, M. (2015). Cellular responses and HSP70 expression during wound healing in Holothuria tubulosa (Gmelin, 1788). Fish \& Shellfish Immunology, 42(2), 306-315.

Vazzana, M., Celi, M., Chiaramonte, M., Inguglia, L., Russo, D., Ferrantelli, V., Battaglia, D., \& Arizza, V. (2018). Cytotoxic activity of Holothuria tubulosa (Echinodermata) coelomocytes. Fish \& Shellfish Immunology, 72, 334-341.

Xing, K., Yang, H.S., \& Chen, M.Y. (2008). Morphological and ultrastructural characterization of the coelomocytes in Apostichopus japonicus. Aquatic Biology, 2, 85-92. 